\title{
The Long Bow \\ or \\ Lucretius, Book IV, Line $817^{\dagger}$
}

Moses Lasky*

For some time a title has been revolving in my mind- "In the Region Where Reason Reels." Naturally, I have rejected it as a piece of unbecoming flippancy, but only to have another title spring up to take its place"In the Land Where Logic Lapses." I knew then that I could not escape the compulsion of dealing with the subject, even though no reader may ever be able to butter any bread with what he reads; he will still have to look up his own law.

My text is a little tidbit from one of Mr. Justice Holmes' letters to Harold Laski, who, I hasten to add as a matter of personal privilege, was quite a different kind of Lasky. I have not been able to place my finger on the text, but it went something like this:

Just because something is possible is not the slightest evidence whatever of its existence.

The temptation is strong to quote Holmes' views on the Sherman Act, as confided privately to Laski. ${ }^{1}$ For example, Holmes once disclosed his opinion that the Sherman Act "is a foolish law," adding"

I have little doubt that the country likes it and I always say, as you know, that if my fellow citizens want to go to Hell I will help them. It's my job.

And again, said he, "I loathe and despise" the Sherman Act and "I am pleased to know that Brandeis, who used to uphold it, doesn't think it does any good." 3

Now I don't share that view, nor do I join with the Laski who spelled his name with an " $\mathrm{i}$ " in replying, "I'm glad you feel the stupidity of the Sherman law ...."

No, my text is the statement,

$\dagger$ Amplified from an address before the Southwest Regional Conference, American Bar Association, April 17, 1955.

* Member, San Francisco Bar.

${ }^{1}$ For a number of comments of Mr. Justice Holmes on the same subject gleaned from the Holmes-Pollock Letters, see Lasky, Metaphysics vs. Reality in the Anti-Trist Law, 26 CAuIT. S.B.J. 28 (1951).

2 Letter to Laski, March 4, 1920, 1 Holmars-LASKI LeTTERS, 248-49 (1953).

${ }^{3}$ Letter to Laski, March 5, 1925, id. at 719.

4 Letter to Holmes, June 3, 1920, id. at 249. 
Just because something is possible is not the slightest evidence whatever of its existence.

And hence I come to the title, for in Book IV, Line 817 of his De Rerum Natura, Lucretius wrote 2000 years ago,

Then, too, from the smallest indications we draw the widest inferences and by our own fault entangle ourselves in the ineshes of self-delusion.

Basically, in the law of antitrust, we start with the vital element of conspiracy. Apart from the limited field of "monopoly," there can be no violation of the Sherman Act without conspiracy. Even under section 2 of the act, the monopoly section, conspiracy plays a major part. Since very few companies possess a monopoly, accusations under section 2 require an aggregation of several compames into one, and it is the charge of conspiracy by which it is sought to coagulate the many into the one. The charge of monopoly is sustainable only when the several are viewed collectively, and this presupposes proof of an unlawful agreement. ${ }^{5}$

How often has an antitrust conspiracy been established by direct evidence? Almost never. We are repeatedly told that conspirators meet in dark secrecy, and since express evidence may not be available, circumstantial evidence is sufficient. Thus in a recent case it was commented: ${ }^{\circ}$

Much is made of the dearth of direct evidence of conspiracy. It must be remembered, however, that "... in this modern era of increasing subtleties, it is rare indeed for a conspiracy to be proved by direct evidence."

No one can quarrel, either as a matter of sense or as a matter of law, with the principle that circumstantial evidence may suffice. But the fact that direct evidence is not available should not mean that no evidence becomes some evidence. The fact that inferences are primarily drawn from circumstances does not mean that a special kind of inference-drawing mechanism may be substituted for the logic of the human mind. Yet in a recent case the able trial judge fairly summed up what seemed to be the state of the antitrust law, thus: ${ }^{7}$

5 United States v. Borden Co, 111 F. Supp. 562, 580 (N.D. Ill. 1953): "Counsel for the government correctly stated during oral argument that the government's cause of action under section 2 of the Sherman Act presupposes a finding that there was an unlawful agreement among the defendants. If the defendants are considered collectively, they certainly do monopolize the market defined in the complaint; but for the reasons stated, the defendants may not be considered collectively."

And as said in United States v. Morgan, 118 F. Supp. 621, 829 (S.D.N.Y.1953) (the Investment Bankers case): "Since there was no combination, the monopoly charges fall of their own weight."

( C-O-Two Fire Equipment Co. v. United States, 197 F.2d 489, 492 (9th Cir. 1952), cert. denied, 344 U.S. 892 (1952), quoting Milgram v. Loew's, Inc., 192 F.2d 579, 583 (3rd Cir. 1951), cert. denied, 343 U.S. 929 (1952).

7 Fanchon \& Marco v. Paramount Pictures, Inc., 100 F. Supp. 84, 89-90 (S.D. Cal. 1951) (per Yankwich, J.). 
As to the manner of proof, the Courts have adopted a liberal attitude, and have permitted inferences of joint action to be drawn from parallel action.

In short, prosecuting lawyers, plaintiffs' counsel and judges draw a Long Bow of inference, loosely strung, in Sherman Forest. Now I inquire: How can a more liberal attitude be permitted here than in any other field? Deduction of fact from fact, by inference, is not a matter of the artificial reasoning of the law, where judges are free to adopt whatever rules, liberal or strict, seem best in the light of public policy. It is a matter of reason and logic, and, if I may be permitted a paraphrase from Holmes' dissent in the famous Northern Securities case: ${ }^{8}$

While at times judges need for their work the training of economists or statesmen, and must act in view of their foresight of consequences, yet when their task is to deduce fact from fact, their function is simple-to reason intelligently.

But, at least until recently, special "logic" prevailed in this field. As a consequence, antitrust trials have consisted of heaping up vast quantities of evidence. Evidence of what? Why, evidence of anything. Throw it all in. Stir it all up; place at the bottom the crust of findings of fact; place on the top the crust of conclusions of law. Here is a pie; the appellate court can dip in a thumb, draw out any plum and exclaim, "The trial court could draw the inference that there was a conspiracy," and then add, with judicial restraint, "It is not the function of this, an appellate court, to substitute its own conclusions."

With the Long Bow aimed at a defendant's heart by our modern merry Robin Hoods, the preparation of the defense of an antitrust case becomes, if not an almost impossible or superhuman task, at least a costly one. To what shall counsel address his mvestigation? What evidence shall he prepare to meet, to explain, to supplement? The answer is everything. Anything at all.

The courts complain of the burden of the Big Case. But it is a burden for which they themselves are responsible, because they do not insist upon the use of ordinary canons of reason and logic.

Let me take some examples at random.

In the famous Interstate Circuit case, ${ }^{9}$ the court held that if two or more

8 In Northern Securities Co. v. United States, 193 U.S. 197, 401 (1904), Mr. Justice Holmes actually said: "Furthermore, while at times judges need for their work the training of economists or statesmen, and nust act in view of their foresight of consequences, yet when their task is to interpret and apply the words of a statute, their function is merely academic to begin with-to read English intelligently-and a consideration of consequences comes into play, if at all, only when the meaning of the words used is open to reasonable doubt."

O Interstate Circuit, Inc. v. United States, 306 U.S. 208 (1939). 
know that concerted action is contemplated, evidence of adherence and participation without evidence of a meeting or an agreement will support a finding of conspiracy. A little later, in the Masonite case, ${ }^{10}$ a conspiracy was held to exist from similarity of action, where all had become aware that their acts were, as the court put it, "part of a larger arrangement." All this has led to the phrase "conscious parallel action." In Milgram v. Loewe' ${ }^{11}$ none of the defendants, the eight major distributors of feature motion pictures, would let plaintiff, a drive-in theatre, have films for first run. The trial court found no evidence of any discussion among the defendants or of common understanding. Nevertheless, it held that there was a conspiracy, resting solely on the Interstate Circuit doctrine. Under that doctrine, it is vital to show, not inerely that competitors follow the same practice, but that they do so with awareness of the others' activities. There was no evidence in the Milgram case of any such knowledge. Yet, the district court found knowledge, and the court of appeals affirned, because it 'termed incredible the distributors' testimony that each acted in ignorance of the others." 12

We should pause and analyze that reasoning for a second. It means that competitors must necessarily know what the others have done; that it is coinmon sense that they should know and therefore is unbelievable that they would not know. With that kind of reasoning, the requirement of knowledge disappears, for it is always present, and the Interstate Circuit doctrine has been reduced to a rule that mere similarity of conduct constitutes conspiracy!

Another example may be taken from the Milgram case. The trial court found "it highly important" that affidavits of top sales executives of the several defendants confirmed the reasoning and decisions of their area managers. Dissenting in the court of appeals, Judge Hastie remembered that in the Interstate Circuit case the Supreme Court had drawn an inference of conspiracy from the failure of defendants to call their top executives to confirm denials by the local agents. He stated: ${ }^{13}$

It seems to me that where the absence of a certain type of testimony has been viewed by the Supreme Court as suggestive of conspiracy in one case, the presentation of such testimony in the next case should not be regarded as affirmative proof of a similar conspiracy.

But in a field where the Long Bow of easy inference is a permissible weapon, where anything can be imferred from anything-or everything from nothing - the demial of a charge proves conspiracy and failure to deny it proves gnilt.

10 United States v. Masonite Corporation, 316 U.S. 265 (1942).

11192 F.2d 579 (3rd Cir. 1951), cert. denied, 343 U.S. 929 (1952).

$127 d$. at 585.

13 Id. at 587 . 
In a case recently before the Ninth Circuit, ${ }^{14}$ where there was no dispute as to the evidence, a conspiracy was inferred from the circumstances. Since that was a criminal case the conclusion had to be beyond a reasonable doubt. Among the facts noted in the opinion as sustaining the inference was the "standardization of the product"-fire extinguishers-and the fact that they were all painted red!

Another fact relied on was that the parties were members of a trade association, attended meetings, and the court said: ${ }^{15}$

[A]n opportunity was thus afforded to discuss and agree upon prices and pricing policies on an industry-wide basis .... [Although, it continued,] there is no direct evidence of what transpired at those meetings ... the trial court, sitting as the trier of the facts, regarded this evidence as being another one in a series of "plus factors" which, when standing alone and examined separately, could not be said to point directly to the conclusion that the charges of the indictment were true beyond a reasonable doubt, but which, when viewed as a whole, in their proper setting, spelled out that irresistible conclusion.

What is this but a statement, contrary to Mr. Justice Holmes' caution, that since it was possible for the defendants to have conspired, the fact was some evidence that they had? If that is so, then it must be added: Since it is equally possible for people to conspire without meeting, in view of the telephone, businessmen can protect themselves from the possibility of conviction only by wearing iron masks over tightly clenched lips and being fed by intravenous injection.

I intend no criticisin of the final decision of these cases. All I know is what I read in the opinions. Other factors relied on were doubtless adequate. But to give weight to elements like those just inentioned adds nothing and merely serves as license to free-booting lawyers and as misleading precedents to hard-worked trial judges.

Sometimes courts have felt the prick of logic at this point, but have often risen triumphantly above it. Outside the antitrust field it is the law -or at least used to be- that $^{16}$

... where proven facts give equal support to each of two inconsistent infer. ences; ... neither of them [is] established [and] judgment, as a matter of

${ }_{14}$ C-O-Two Fire Equipment Co. v. United States, 197 F.2d 489 (9th Cir. 1952), cert. denied, 344 U.S. 892 (1952).

15 Id. at 493.

16 Pennsylvania R. Co. v. Chamberlain, 288 U.S. 333, 339-40 (1933). As the court also put it, "... [W] [Wen the evidence tends equally to sustain either of two inconsistent propositions, neither of them can be said to have been established by legitinate proof. A verdict in favor of the party bound to maintain one of those propositions against the other is necessarily wrong." Id. at 340. See also Gunning v. Cooley, 281 U.S. 90, 94 (1930); but contrast Labor Board v. INevada Consolidated Copper Co., 316 U.S. 105 (1942), where the power of the NLRB to draw one of two inconsistent inferences was upheld because the National Labor Relations Act made the Board's findings conclusive if supported by evidence. 
law, must go against the party upon whom rests the necessity of sustaining one of these inferences as against the other, before he is entitled to recover.

And in criminal cases there is a standard that guilt may be found on circumstantial evidence, not merely if the facts are consistent with guilt, but only if they are inconsistent with any other reasonable hypothesis.

These standards were applied in one refreshing antitrust case, Peveley Dairy Co. v. United States. ${ }^{17}$ In the fire extinguisher case the court said that it was not unmindful of the standard suggested in Peveley but then dismissed it with the statement: ${ }^{18}$

But that is not to say ... that such a rule must be separately applied to each Jink in the chain of circumstances and if one such unit does not fit the standard then the whole is likewise vulnerable.

Why not? If a sufficient number of grains of sand is piled up, they may eventually weigh a ton. But the heaping up of zeros can still be only zero. Nothing added to nothing is still nothing. ${ }^{19}$ The standards about the drawing of inferences are not creations of the artificial reasoning of the law; they are required by the rational processes of the human mind.

The kind of, should I say, reasoning found in antitrust cases substitutes "judgment by hunch" for judgment by reason ${ }^{20}$ and makes unfounded assumptions about life and human nature. It assumes that people will be crooked if given the chance, and it ignores a truth that architects and designers know, that form follows function, and a truth that anthropologists recognize, that people react in similar ways to similar situations; so that the same problems in an industry will produce similar modes of meeting them among competitors.

The Long Bow has introduced an exceedingly neat method of proving a conspiracy. Let me see if $I$ can state it in a series of steps. It starts with the fact that although conspiracy is the gravamen of the case, it is not necessary to have any evidence of an express agreement either written or oral.

1. First, if you are to be the prosecutor or plaintiff's counsel, resolve to deduce the inference from acts, policies, practices and circumstances.

2. Next, survey the particular industry you intend to raid or reform,

17178 F.2d 363 (8th Cir. 1949), cert. denied, 339 U.S. 942 (1950).

18 C-O-Two Fire Equipment Co. v. United States, 197 F.2d 494 (9th Cir. 1952), cert. denied, 344 U.S. 892 (1952).

10 Yet candor requires the admission that somewhere one of the justices of the United States Supreme Court has called it error to believe that in the law the sum of items, each of which has no tendency to prove anything, also proves nothing. The whole is greater than the sum of the parts, Euclid to the contrary notwithstanding. As in Orwell's "1984," two plus two may be five, if socially desirable.

20 There is a place for the "hunch"; cf. discussion by Judge Hutcheson, 14 CoRNenx L.Q. 274 (1929), on "the judgment intuitive" and the function of the "hunch." But it does not go this far. 
and tabulate or catalog all the acts, conduct and characteristics which are found to be existent in that industry. In this process, put out of your mind the truth that form follows function.

3. The next step is to frame an allegation in your complaint or indictment to the effect that there was a general conspiracy, agreement or concert of action to perform this particular collection of acts and to achieve this particular set of characteristics.

4. At the trial, diligently prove the existence of this set of facts and characteristics. This ought not be difficult.

5. Behold, you have established that the acts alleged did occur and that the characteristics charged did exist. Then string and twang the Long Bow. Ask that a conspiracy to do the acts be inferred from the fact that they were done. Why not? Is there not a remarkable correlation of fact proved with charge?

This, I say, is an exceptionally neat procedure. And it represents the heart and core of many a case brought by the Government and by the private plaintiff.

In the Tobacco case $^{21}$ the court said: ${ }^{22}$

No formal agreement is necessary to constitute an unlawful conspiracy. Almost always, the crime is a matter of inference, deduced from the acts of the persons accused, which are done in pursuance of an apparent criminal purpose.

Please supplement this observation with the realization that in the antitrust field the criminal purpose arises from the fact that the acts, otherwise legal, are done in conspiracy. Then, you see, the conspiracy is deducible as an inference, if only the conspiracy be first assumed. This is a very neat bit of boot-strap hifting.

And that assumption is not a difficult one to make, because, as every experienced lawyer knows, guilt and fraud are always presumed, and the burden is upon the accused to disprove them. Let the reader not look startled. Let him not be confused by the noble theory graven over the lintel of courthouses to the contrary. The reality was once pithily stated by Justice Grier in a jury charge, while on circuit in 1850. I shall quote a passage, because though long, it is apt: ${ }^{23}$

It does not require a great deal of ingenuity to cast suspicion of fraud upon any transaction. There is a very great ... error into which ... jurors and judges ... are apt to fall; and which leads to false judgments, and sometimes to great oppression. . . It is this: ... Every honest inind hates

21 American Tobacco Co. v. United States, 147 F.2d 93 (6th Cir. 1944), aff'd, 328 U.S. 781 (1946).

22 Id. at 107.

23 Turner v. Hand, 24 Fed. Cas. No. 1425\%, at 362 (C.C. N.J.1855). 
[fraud], and even those who practice it themselves, will join in the denunciation of it. It makes thein feel virtuous . ..., and they are the most ready ... from judging of others by themselves, to believe it true . . . . When ... fraud is ... confidently charged ...., we are prone to see all facts through a false medium, which inagnifies the importance of every fact from which suspicion of fraud may be raised, and ignores the plainest inference against it. In the midst of our virtuous indignation against fraud, we first assume it has been committed, and then seek for arguments to confirm, not our judgments, but our prejudice. "Trifles, light as air," then become "strong as proofs of holy writ." Circumstances which to an unprejudiced mind are just as compatible with innocence as guilt; which at best could only raise a suspicion, are set down as conclusive evidence of crime. Those who sit in judgment over men's rights, whether as courts or jurors, should beware of this natural weakness .... We all fancy ourselves wiser than perhaps others are willing to give us credit for.... Rogues may be cunning, but they can't deceive us. Under this satisfactory belief, we become overastute .... We suffer our imaginations to take the rein from our judgments, and rush headlong in this chase after the fox called fraud. ${ }^{24}$

Once again, I may refer to a comment by Justice Holmes in a letter to the other Laski. Said he: ${ }^{25}$

Probably I have told you ... of seeing on the fences just after our war [World War I] an advertisement ST $1860 \mathrm{X}$ and saying and proving to myself that if one accepted that as a revelation of the ultimate secret, one would be surprised at the corroboration that a fortnight could develop.

24 This same thought has been expressed without benefit of quotation marks in Dailey v. Wight, 51 Atl. 38, 39 (Md. 1902) thus:

If the examination of a question of fact be approached with the preconceived conviction that fraudulent conduct is hidden somewhere behind it, it is altogether likely that an entirely false coloring will be involuntarily given to perfectly innocent transactions. The assumption that fraud has been practiced, and the assumption of this in advance of an actual knowledge of the facts really existing, is often apt to mislead the judgment of the otherwise cautious investigator when he coines to the consideration not of the supposed, but of the actual, events and occurrences, and thus frequently "trifles light as air" become "confirmations strong as proofs of holy writ."

And the same idea has been turned upside down in Merchants' National Bank v. Greenhood, 41 Pac. 250, 259 (Mont. 1895):

Fraud cannot often be proven by direct evidence. Fraud conceals itself. It does not move upon the surface in straight lines. It goes in devious ways. We may with difficulty know "whence it cometh and whither it goeth." It "loves darkness rather than light, because its deeds are evil." It is rarely that we can lay our hand upon it in its going. We are more likely to discover it at its destination, before we know that it las started upon its sinuous course. When we so discover it, the search light of a judicial investigation goes back over its trail and lightens it from beginning to end. As the woodsman follows his game by shight indieations, as a broken twig or a displaced pebble, so fraud may become apparent by innumerable circumstances, individually trivial, perhaps, but in their mass "confirmation strong as proofs of loly writ." The weight of isolated items tending to show fraud may be "as hight as the shadow of drifting snow," but the drifting snow in time makes the drift, the avalanche, the glacier. Fraud may hang over the history of the acts of a man like the leaden-lued atmosphere upon the house of Usher, "faintly discernible but pestilent, an atmosphere which has no affinity with the air of Heaven."

25 Letter to Laski, January 23, 1928, 2 Holmes-LASKr LeTrers 1020 (1953). 
And so it has been in the antitrust field. Assume that a conspiracy exists, and it is amazing what corroboration will be supplied by digging into industry files and dragging out old papers, any papers at all. As a consequence, attorneys for business must develop a sort of diseased mind coupled with a mystic prescience. In passing on papers in current transactions they must try to envisage how innocent phrases may be twisted in the future to support charges that one must struggle to imagine.

In a current case the defendants are charged with combining and conspiring to monopolize, and with having actually monopolized, commerce in a certain line of products, and a vast number of industry practices are heaped up in the complaint. One is that the defendants make exchanges with each other so that each is able to obtain the product for sale in a marketing area where it does not produce and to which it has no transportation facilities. Asked how it supported its claim that exchanges operated to produce a monopoly, plaintiff answered that they showed a willingness of the defendants to assist each other in the penetration of markets instead of each reserving to itself the competitive advantages which it might possess by reason of the possession or location of facilities. This means that the defendants do not insist on any natural monopoly they may have. From the fact that each is willing to forego a legal monopoly, the plaintiff infers a conspiracy to form an illegal one. Plaintiff further answered that from the willingness of the defendants to make exchanges is to be "inferred" "the existence of a tacit agreement" that those enabled by exchange agreements to enter markets not otherwise economically accessible to them will not disturb the price structure or otherwise vigorously compete to take customers or business away.

The tacit premise here is that men are by nature law-violators or governed by base motives, and from this premise it is to be inferred that they would not let another party compete with them unless they receive, as a quid pro quo, an illegal promise! Such is the premise that underhes so much inference in the antitrust field.

If time and space permitted, it would be illuminating to contrast the Long Bow in antitrust cases with the short bow tightly strung in other cases, for example where the Supreme Court wishes to sidestep a sensitive constitutional question. If the reader is interested in pursuing that avenue, he may look at United States v. Guy W. Capps, Inc., ${ }^{26}$ which involved an executive agreement with Canada limiting the export of Canadian potatoes to this country to prevent competition with our price support program. Importers had to promise that the potatoes would be used for seed. Capps was sued by the United States for breaking the promise. The court of ap-

26348 U.S. 296 (1955). 
peals, speaking through its very able Chief Judge Parker, noted that Capps "sold the potatoes while in shipment to the Atlantic Commission Company, a wholly owned agency of Great Atlantic \& Pacific Tea Company, a retail grocery organization," reviewed the evidence, and concluded that "we have little difficulty in seeing in the evidence" enough to allow a jury to infer a breach of the contract. ${ }^{27}$ But the court affirmed a directed verdict for defendant on the ground that the executive agreement had no legal effect. Since this landed in the middle of the Bricker Amendment controversy, the Supreme Court granted certiorari. Then by a nice analysis of the facts, it found the inference impossible and thus avoided the necessity of deciding the constitutional question.

Had Capps been charged with conspiracy with the Great A. \& P. and the Atlantic Commission Company to divert the potatoes, and had such a diversion been relevant to a monopoly in potatoes, I refuse to believe that the evidence would not have been held ample to sustain the inference.

It is but natural to wonder why the loose inference sprouts so easily in the antitrust field. We may list two reasons:

In the Texas City Explosion case, ${ }^{28} \mathrm{Mr}$. Justice Jackson, a master of the pungent phrase, remarked that "[t]he Government, as a defendant, can exert an unctuous persuasiveness because it can clothe official carelessness with a public interest." ${ }^{29}$ So, in a prosecution or in a civil action, the government can assert an unctuous persuasiveness because it can clothe fallacious reasoning with the public interest. This is the first reason, and its consequences sometimes spill over into the private suit. There is slavery of phrases. Round statements made by courts in government suits are picked up and added mechanically, for the compiling of authorities and the multiplication of citations are often easier than analysis.

The second reason is that the Sherman Act expresses a basic philosophy of a free competitive society. Because this is an intensely sound attitude, it has become one of the Holy of Holies of American life. In the presence of the Ark of the Covenant the rational mind bows down.

The subconscious train of ideas runs about like this: Every law must have violators, and this particular law must be enforced. To enforce it, there must be convictions. If one caunot find a conspiracy, one cannot convict. Therefore, if conspiracy cannot be proved, it must be inferred.

For example, in the fire extinguisher case, the court of appeals justified its approach by saying: "Proof of a formal agreement is unnecessary, and were the law otherwise such conspiracies would flourish; profit, rather than pumisliment, would be the reward." 30

\footnotetext{
27 Id. at 301.

${ }^{28}$ Dalehite v. United States, 346 U.S. 15 (1953).

29 Id. at 50 .

${ }^{30}$ C-O-Two Fire Equipment Co. v. United States, 197 F.2d 489, 494 (9th Cir. 1952), cert. denied, 344 U.S. 892 (1952).
} 
No doubt there are antitrust conspiracies so concealed that, if the ordinary canons of proof prevail, the proof cannot be made. If so, violation of the law should go unpunished. The desire that wrong should not go unwhipped of justice is commendable, but it is hardly a reason for abandoning the requirements of logic. The use of a statute that makes conspiracy the crime, as a tool to reach economic abuses or to reform industrial structures thought to be inimical to the public welfare, is more than a farce. The body of the law suffers a sorer wound if reasoning and logic are defied than if an occasional law-violator goes free. Either conspiracy should be proved, or else the statute should be amended to establish other tests of illegality.

Perhaps, as an antidote, it would not be amiss to recall that so recently as 1953 the Supreme Court said: ${ }^{31}$

That there is a national policy favoring competition cannot be maintained today without careful qualification. It is only in a blunt, undiscriminating sense that we speak of competition as an ultimate good. Certainly even in those areas of economic activity where the play of private forces has been subjected only to the negative prohibitions of the Sherman Law, this Court has not lield that competition is an absolute.

Fortunately, the law is a remarkable structure. In these days, when we hear of automation, feed-back, and "servo-mechanisms," the legal profession can take pride that the law, with its constant flow of litigation and opinions, was perhaps the first of the self-adjusting machines. Excesses tend to be smoothed out. Recently a number of courts have become alert to the fact that reason and logic are entitled to no moratorium in the antitrust field.

A few pages back I quoted Mr. Justice Grier's warning to a jury against the tendency to regard "trifles, light as air . . . as proofs of holy writ" in fraud cases. Recently Chief Judge Hutcheson of the Fifth Circuit, in affirming the dismissal of certain charges in antitrust pleadings, used language so similar as to suggest familiarity with this statement. Said he: ${ }^{82}$

Charges as to such conspiracies must be based on substantial and affirmative allegations, and no mere gossamer web of conchusion or inference, as here, trifles light as air, to the suspicious strong as proofs from Holy Writ, will suffice....

Since a valuable truth vividly expressed lias now been applied to the antitrust field by an outstanding appellate judge, we may hope to see the Grier charge adapted from fraud to conspiracy and given to a jury in an antitrust case. The law would be the better for it.

Earlier in this article I noted Judge Yankwich's statement about the

31 Federal Communications Commission v. RCA Communications Inc., 346 U.S. 86, 91 (1953).

32 Crummer Company v. duPont, 223 F.2d 238, 245 (5th Cir. 1955). (Emphasis added.) 
liberality of proof allowed to prove conspiracy in antitrust cases. But he immediately added: "But, regardless of burden of proof, in the last analysis, the trier of facts must be satisfied that the practices which the plaintiff claims to have injured him were the result of joint action ...." ${ }^{33} \mathrm{He}$ found no conspiracy; and, in affirming, the court of appeals cast a doubting eye on Milgram v. Loew's, ${ }^{34}$ although in its earlier fire extinguisher case it had been influenced by that case.

In a decision of last December, ${ }^{35}$ a summary judgment for defendants was granted by Judge Rodney. Stating that while conspiracy may be shown by inference from circumstantial evidence, the court remarked: ${ }^{36}$

[T] he word "inference" must be given its true meaning of a logical conclusion from given data or premises and not a conclusion or thought that has no reasonable basis for its existence .... "An inference is but a reasonable deduction and conclusion from proven facts."

\section{In the Investment Bankers case ${ }^{37}$ Judge Medina remarked: ${ }^{38}$}

The task of the judge is to determine whether the conduct challenged in the litigation contravenes the prohibitions of the statute. This is no mandate to the judiciary to decide anti-trust cases according to individual ideas of expediency, which may change according to the personal philosophy or even the political affiliation of the judge. It is the combination or joint action of the many which is the essence of the offense. Unless there is some agreement, combination or conspiracy the Sherman Act is not applicable.

But it is supposed by some that the requirement of combination is a mere empty phrase to which one must indeed do lipservice, but which may easily be got around by finding agreement, combination or conspiracy when in truth and in fact no agreement, combination or conspiracy exists, provided the result obtained seems desirable and in the public interest. This is not the law but only another aspect of the false but seductive doctrine that the end justifies the means which, so far as I know, has never taken lodgment in American jurisprudence; and I hope it never will.

True it is that conspiracies whether by business men or others engaged in unlawful schemes are often hard to detect. No direct proof of agreement between the wrongdoers is necessary; circumstantial evidence of the illegal combination is here as elsewhere often most convincing and satisfactory. But, when all is said and done, it is the true and ultimate fact which must prevail. Either there is some agreement, combination or conspiracy or there is not. The answer must not be found in some crystal ball or vaguely sensed

33 Fanchon \& Marco v. Paramount Pictures, Inc., 100 F. Supp. 84, 90 (S.D. Cal. 1951).

34 Fanchon \& Marco, Inc. v. Paramount Pictures, Inc., 215 F.2d 167, 168 n.1 (9th Cir. 1954).

35 United States v. L. D. Caulk Co., 126 F. Supp. 693 (D.C.Del. 1954).

36 Id. at 702.

37 United States v. Morgan, 118 F. Supp. 621 (S.D.N.X. 1953).

$38 \mathrm{Id}$. at 634. (Emphasis added.) 
by some process of intuition, based upon a chance phrase used here or there, but in the evidence adduced in the record of the case . . . ${ }^{39}$

Courts are now recognizing that similarity of conduct by itself proves nothing; for example, in this language: "Reasonable businessmen will act similarly when presented with the same problem." 40

In January 1954, the Supreme Court had before it a case ${ }^{41}$ where the plaintiff had charged defendants with conspiring to restrict first-run motion pictures to downtown theatres. The jury had returned a verdict for defendants, and the plaintiff urged that the trial judge should have directed a verdict for the plaintiff. There was "no direct evidence of illegal agreement," but the defendants had "advanced much the same reasons" for refusing to give first-run pictures to plaintiff. The Supreme Court said: ${ }^{42}$

The crucial question is whether respondents' conduct toward petitioner stemmed from independent decision or from an agreement, tacit or express. To be sure, business behavior is admissible circumstantial evidence from which the fact finder may infer agreement .... But this Court has never held that proof of parallel business behavior conclusively establishes agreement or, phrased differently, that such behavior itself constitutes a Sherman Act offense. Circumstantial evidence of consciously parallel behavior may have inade heavy inroads into the traditional judicial attitude toward conspiracy; but "conscious parallelism" has not yet read conspiracy out of the Sherman Act entirely.

Thus the Supreme Court has said what never should have been necessary to say, that consciously parallel business behavior is not conclusive proof of conspiracy. This is a first step toward reason. It is good, so far as it goes, and to go further would have been dictum in the particular case. But the courts must go further; the issue will be sharply presented when a jury returns a verdict for the plaintiff rather than defendants, solely on evidence of similarity of conduct. When the issue arises, we shall see whether the

39 Judge Medina also said: "The Sherman Act is not an open door through which any court or judge may pass at will in order to shape or mould the affairs of business men according to his own individual notions of sound economic policy." United States v. Morgan, 118 F. Supp. 621, 633 (S.D.N.Y. 1953).

Again, he remarked: "In my judgment, the only hope of cutting these conspiracy cases down to size, bes in the exercise of a sound discretion by the Department of Justice. The trial judge, desirous of doing full justice to all parties, can bardly lop off particular segments of the case at a time when it is impossible to be sure that they will or will not, in the end, fit together." Id. at 827 .

Compare with this opinion Judge Wyzanski's reniarks in United States v. United Shoe Machinery Corp., 110 F. Supp. 295, 314 (D.C. Mass. 1953). He referred to "the degree to which the Government had unnecessarily increased the burden resting on the parties and the Court" by "the unforgivably unselective tactics pursued by" it, and declined to refer to some of its evidence for fear of "encourag [ing] the repetition in later antitrust bitigation."

40 United States v. Borden Co., 111 F. Supp. 562, 579 (N.D. Ill. 1953).

41 Theatre Enterprises, Inc. v. Paranıount Film Distributing Corp., 346 U.S. 537 (1954). 42 Id. at $540-41$. 
Supreme Court is prepared to say that, by itself, conscious parallel business behavior is no evidence at all of conspiracy. Only the other day the Supreme Court of Texas so held in a case under the Texas antitrust act, ${ }^{42 a}$ and it was able to do so on the complaint by a procedural quirk made possible by the intellectual honesty of counsel for the State. We have yet to see a similar decision under the federal act, but one district court has already cited the Theatre Enterprise case as authority for holding that "conscious parallel action" was not unlawful and that "the mere fact that under the circumstances presented, each knew what the others were doing and in some instances nearly contemporaneously did the same thing, does not, without more, make out an unlawful conspiracy." 43

Adam Smith, in his The Wealth of Nations, remarked: ${ }^{44}$

Two greyhounds, in running down the same hare, have sometimes the appearance of acting in some sort of concert. Each turns her towards his companion, or endeavors to intercept her when his companion turns her towards himself. This, however, is not the effect of any contract, but of the accidental concurrence of their passions in the same object at that particular time.

Smith's system of economics may be questioned, but the keenness of this observation may not. In the competitive race to catch the hare, the consumer's dollar, the appearance of concert is more likely to be the effect of the accidental concurrence of pursuit of the same object than the effect of conspiracy..$^{45}$

The Federal Trade Commission used to draw a Longer Bow than anybody else, but for a while, at least, it seemed to have reformed. In a very recent case ${ }^{46}$ it issued a cease and desist order against a number of trade associations and distributors but, contrary to the recommended decision of the hearing officer, dismissed the complaint against (believe it or not) 900 other merchants. Concurring, Commissioner Lowell Mason said in one of his witty opinions:

Here we are shown the petty machinations of a dozen over-enthusiastic trade association members. With no other link to their illegal agreements

42a Arkansas Fuel Oil Company v. State, 280 S.W.2d 723 (Tex. 1955).

43 Interborough News Co. v. Curtis Publishing Co., 127 F. Supp. 286, 301 (S.D. N.Y. 1954).

44 Book I, chapter II, second paragraph.

45 Something in the subject seems to require the metaphor of a chase by hounds. In KieferStewart Co. v. Seagram \& Sons, Inc., 182 F.2d 228 (7th Cir. 1950), rev'd, 340 U.S. 211 (1951), a conviction was reversed where one manufacturer had followed the policy of another in refusing to sell to certain distributors, remarking: "This action ... does not prove or tend to prove that it was done by agreement ... any more than proof that a hound is chasing a fox is evidence that the chase is by agreement of the fox." Id. at 233. And see the last sentence quoted from Mr. Justice Grier's charge in Turner v. Hand at note 23 supra.

${ }^{46}$ National Paper Trade Association of the United States, Inc, 3 CCH Trade Reg. Rep. II 25,194 (Sept. 24, 1954). 
than a common membership in a trade association, we are opportuned to hack away at the entire wholesale paper trade industry exclaiming, "Everybody in the industry is a conspirator"!

When the Government attempts to parlay a conspiracy suit valid against a hundred defendants into a cease and desist order against a thousand for no reason other than that they all belong to trade associations, it's time we took one look at the charge, two at the evidence, and three long looks at the procedures which defile so many on so little.

The procedure involves the combination of a conspiracy charge and a class suit with a finding of guilt by association.

....

Granting that precedents are established for all three concepts in our judicial process, the wedding of the three together cannot help but to greatly accent (as in a consanguineal marriage) the most vicious attributes einbodied in each.

We have been in sore need that courts in antitrust cases examine the evidence with a jaundiced eye. I think that we now may be getting this.

But curious logic and novel reasoning processes have not been restricted in antitrust to "inferences" of fact. They have also bred odd rules of law, and I nuay add to my text another of Holmes' comments to Laski: "I think it [the Act] has been enlarged by construction in ways I regret." 47

Difficult and jaw-breaking rules of law arise because the fact-finding machinery of the legal systen strips its gears. In despair at finding where truth lies, or in despair at finding the kind of facts necessary to permit desired conclusions, judges develop an armory of rules. So it is in the field of antitrust. A vast amount of strange law has grown up. Take, for example, the Robinson-Patman Act; section 2(a) prohibits price discriminations in the sale of goods of like grade and quality where the "effect . . . may be substantially to lessen conpetition ... or to injure, destroy or prevent competition ...." In the Corn Products case, ${ }^{48}$ the court said, "It is to be observed that section 2 (a) does not require a finding that the discriminations in price have in fact had an adverse effect on conpetition. The statute is designed to reach such discriminations 'in their incipiency,' before the harin to competition is effected. It is enough that they 'may' have the prescribed effect." 40

And it added, a few pages further on, "As we have said, the statute does not require that the discriminations must in fact have harmed coinpetition, but only that there is a reasonable possibility that they 'may' have such an effect."

47 Letter to Laski, March 5, 1925, 1 HoLsres-Laski LeTrers 719 (1953).

48 Corn Products Refining Co. v. Federal Trade Commission, 324 U.S. 726 (1945).

$49 \mathrm{Id}$. at 738. (Emphasis added.) Quoted and approved in Federal Trade Commission v. Morton Salt Co., 334 U.S. 37, 46 (1948).

50 Corn Products Co. v. Federad Trade Commission, 324 U.S. 726, 742 (1945). (Emphasis added.) 
One cries for help from some savant of logic, for here we are given the concept of the "possibility of a probability." A "possibility," I should think, means the capability of something being or becoming an actuality. A "probability" means something more than a mere capability. It means that what lies in the womb of possibility is reasonably likely to be born. But what in the name of Lucretius is "a possibility of a probability"? If we turn it on its liead and ask, what is a "probability of a possibility," we must conclude that it is a pure tautology, for the merely possible can never be more probable in one case than another. A "possibility of a probability" must be something less likely to happen than the probable, since it is not the possibility of the actual but the possibility of the merely likely.

How can the human mind operate with tests such as these? This is the abandonment of human reason, and the abandonment of reason is the abandonment of the jural system. In the Morton Salt case, ${ }^{51} \mathrm{Mr}$. Justice Jackson summed up the matter thus: "The law of this case, in a nutsliell, is that no quantity discount is valid, if the Commission chooses to say it is not." ${ }^{2}$ Where the correctness of a finding of fact rests in the readiness of the finder to make it, there is no law.

In a recent case before the Federal Trade Commission, ${ }^{53}$ where price discriminations were establisled, the Commission offered no evidence on the issue whether there liad been injury to the customers who had received the lesser discounts. On tlie contrary, a number of those customers testified on respondent's behalf that they had not been injured, and the Commission's counsel stipulated that if all other customers who had received the lesser discount were called as witnesses, they too would deny that they had been injured. Nevertheless, the Commission issued its cease and desist order. The particular decision may have been correct on the record, ${ }^{54}$ but the remarks of Commissioner Mason, dissenting, are of interest. Conceding that under the "carte blanche authority" granted by the Corn Products and Morton Salt cases the Commission could draw the inference of injury from the mere fact of differences in price "if [it] chose" to do so, without introducing any evidence on the subject of injury, lie believed that when a respondent introduced affirmative evidence, the right to draw the inference vanished.

For inferences and facts are two different things. Their standing might be compared to mistresses and wives.

Inferences are compliant things, swaying to the whim of those who draw them. While facts, like wives, can be harsh, unbending, and often block the

\footnotetext{
51 Federal Trade Commission v. Morton Salt Co., 334 U.S. 37 (1948).

52 Id. at 58.

53 Moog Industries, Inc., 3 CCH TrADE REg. REP. If 25,444 (May 19, 1955).

54 Chairman Howrey concurred on the ground that "the record contained direct and substantial evidence showing probability of injury to competition."
} 
selfish aims of those who must live with them; they do nevertheless carry a badge of legitimacy that no unsupported inference has ever been able to achieve.

Like a belligerent wife crashing in on an assignation with a hussy, the direct testimony of the alleged injured customers that they in fact were not injured, broke up the inference of injury so necessary to the Government's case.

In spite of this, my learned majority of the Commission has

"Divorced Cold Solid Reason from its bed

And taken Inferences Instead" [adding in a footnote his apologies to Omar Khayyam.] ${ }^{55}$

Another of the curious developments in the antitrust law concerns section 2 of the Sherman Act, the monopoly section. Although the courts started to work much later on this section than on section 1 , which deals with the conspiracy to restrain trade, they succeeded more quickly in reducing it to a shapeless mass and producing a state of law comparable to one of the adventures of Baron Munchhausen.

Unlike conspiracy, monopoly, it is said, requires "power" to exclude others from competition, as well as "intent" to do so. But the exercise of the power is not necessary. One may violate the law though he does not use his power and does not in fact exclude others. ${ }^{56}$ And if the "power" exists, the "intent" to use it may be supplied by inference from a past use of it."

It once was to be said that mere size is not condemned by the law. ${ }^{58}$ But soon the courts whittled away at this by saying that size, though not illegal per se, shows the existence of power," and the "mere existence of monopoly power . : . is some indication of illegality." ${ }^{80}$ If mere existence of the power is some evidence of illegality, what makes the power illegal? The answer has been given: "Nothing more than a purpose or intent to exercise the power." This intent may be manifested if the power "comes about as a consequence of defendant's conduct or business arrangements." But that conduct need not have included a single abuse, a single unfair thing or a single illegal act. Thus the Aluminum Corporation was held to be an illegal monopoly for no other reason than that its officers were alert to the possibilities of development and of public demand and had new plant facilities available when the demand appeared. ${ }^{61}$ Business foresight was thus the root of illegality.

55 Moog Industries, Inc., CCH TRADE REg. REP. $\| 25,444$ (May 19, 1955).

56 American Tobacco Co. v. United States, 328 U.S. 781, 809 (1946), approving United States v. Aluminum Corp., 148 F.2d 416 (2d Cir. 1945), and United States v. Aluminum Co., 91 F. Supp. 333 (S.D.N.Y. 1950).

57 United States v. Swift \& Co., 286 U.S. 106 (1932).

58 United States v. United States Steel Corp., 251 U.S. 417 (1920).

50 American Tobacco Co. v. United States, 328 U.S. 781, 796 (1946).

60 United States v. Aluminum Co., 91 F. Supp. 333, 342 (S.D.N.Y. 1950).

61 Ibid. 
It is also said that if the power has been acquired by a conspiracy in violation of section 1 , with the intent to exercise the power, it is illegal, though not exercised. ${ }^{62}$

All this leads to an odd consequence. An agreement to restrain trade is an illegal conspiracy, though nothing is done under it. ${ }^{63} \mathrm{~A}$ conspiracy among a sizeable portion of the industry creates the power to exclude competitors, if exercised. Therefore a mere agreement to restrain though nothing be done under it creates the power as well as displays the intent. This adds up to monopolization, though it is not exercised. It is also a conspiracy to monopolize. ${ }^{64}$

Thus three different crimes are committed by one mental state, a conspiracy to restrain trade, a conspiracy to monopolize, and monopoly itself. This is what reminds one of the Adventures of Baron Munchhausen, for the reader may remember that with one shot the good Baron brought down 50 brace of ducks, 20 widgeons and 2 teal.

Earlier I cautioned, in view of certain decisions, that businessmen can be safe from possibility of conviction only by never speaking. If one mental state can constitute three crimes, the caution must be amphified: Businessmen can be safe only by never thinking.

One could go on with a few more marvelous consequences of some of the utterances in the law of monopoly ${ }^{65}$ But having already spanned the centuries from Lucretius, who reduced all reality to the imperceptible, to Baron Munchhausen, who delighted in the unbelievable, perhaps enough has been done to bound this wondrous field of antitrust.

\footnotetext{
${ }^{82}$ American Tobacco Co. v. United States, 147 F.2d 93, 110 (6th Cir. 1944).

63 See Lasky, Metaphysics v. Reality in the Antitrust Law, 26 CaIr. S.B.J. 28 (1951).

64 American Tobacco Co. v. United States, 147 F.2d 93, 111 (6th Cir. 1944).

65 Since a single party need not have the power to exclude competition, but it may be found merely by adding together the position of several factors in an industry by conspiracy, and since conspiracy may mean no more than similarity of action not illegal in itself, American Tobacco Co. v. United States, 328 U.S. 781, 809 (1946), one might conclude that if there are only a few companies in an industry, similarity of pricing will constitute a "monopoly." Diversity of pricing will probably result in driving the companies with the higher price out of business. This will result in a real monopoly. Thus, no matter what is done or not done, the law is violated. Perhaps the monstrousness of the conclusions to which some of the premises stated by the courts seem to lead, if pursued to their logical end, may induce the courts to re-examine the premises. Or perbaps the courts may insist on drawing the conclusions. One never knows.
} 